\title{
Multicultural education policies in the Spanish region of Castilla La Mancha
}

\author{
Alonso Mateo Gómez*, Raquel Bravo Marín** \\ *Castilla La Mancha University, Spain; Alonso.Mateo@uclm.es \\ **Castilla La Mancha University, Spain; Raquel.Bravo@uclm.es
}

\begin{abstract}
Multiculturalism as the coexistence in the same society of persons from different cultures poses a challenge to our contemporary societies. The role of education is basic to face the opportunities and potential problems of multiculturalism. In Spain educational system is decentralized, therefore, the different autonomous regions can establish laws related to education within their territories. The model of multicultural education in Castilla La Mancha is directly related to social cohesion and has a commitment to inclusive education. This implies the transformation of teaching practices, as well as changes in the schools' culture and organization. Intercultural education pursues equity, intercultural competence, social transformation and the fight against discrimination. An inclusive school is characterized by a high commitment of teachers and a positive attitude towards heterogeneous groups, because they are the reflection of our society. This will result into an effort to offer human, material or technical, support in the ordinary classroom.
\end{abstract}

Keywords: multiculturalism, social change, education, educational inclusion

\section{Introduction}

In the last decades the Spanish educational system reflects a cultural diversity defined by the traditional Spanish cultural reality, currently organized in autonomous regions; the progressive integration of Spain in the European Union; the gypsy minority and recent immigration (Muñoz Sedano 1997). These fundamentals should orientate the design of multicultural education programs that could respond to the diversity of Spanish society. However, as Aguado Odina (2000) argues, educational systems, agents and institutions do not recognize the deeper need for change that goes beyond certain surface measures and that affects the culture itself experienced and transmitted by the school.

Together with the change experienced in the Spanish schools, the Castilla La Mancha region has experienced deep changes in the composition of its society and schooling system. The schools have students who are increasingly diverse in origin. Different nationalities, cultures and religions are mixed in the classrooms. As a result, the educational system must be adapted to the new reality. This situation has also been experienced in the rest of the world. Migratory phenomena have been producing multicultural societies, and in each of them assimilation is occurring with different types of traits.

The OCDE (Organization for Economic Co-operation and Development) elaborated the TALIS (Teaching and Learning International Survey 2018). The survey concluded that it is essential that governments and educational administrations are aware of the need of training teachers to educate in multicultural environments. This specific preparation is fundamental, in order to adequately address the differences presented by the students from different cultures, both in their previous knowledge and skills and in strategies. As explained in the TALIS report, multiculturalism is based on the premise that diversity can enrich schools as it fosters knowledge and respect for other cultures, strengthen intercultural skills and value diversity. Cultural diversity can be seized to create better citizens and, therefore, a better society. Taking into consideration the common culture policies promoted by the European Union to favor the coexistence of European citizens, with persons from other countries, there is a need for professionals dedicated to education in different teaching contexts, increasingly aware and able to apply strategies that contribute to these purposes.

In a broader context, intercultural education demands a series of actions that must be implemented for all the people in a society, and not only for members of one of the cultures. It involves active citizenship, so that the benefits can reach the whole society. This approach is known as the holistic 
model, which is integrated by the intercultural and socio-critical approach (Banks 1986, 1989). It implies the involvement of the entire school in multicultural education. It also emphasizes the fact that its application must be carried out with all the students and not only with foreign or minority students.

In this model, the contribution of the school to social construction is underlined, involving students in a critical analysis of social reality and in action projects that suppose a fight against inequality. According to Banks $(1986,1989)$, it is important to create school environments where the members have and democratic, non-racist values and attitudes. The school must have norms and principles that reflect cultural and ethnic diversity. Likewise, the curriculum and teaching materials must contain diverse ethical and cultural perspectives.

Linguistic pluralism and diversity have also to be valued in school. It is important that effective ways and styles of motivation are used, not only with students of the host culture, but also with groups of students of different social classes, origins or ethnicity. It is crucial that teachers and students acquire the skills and perspectives necessary to recognize the various forms of racism and develop actions to remove them. Banks (1989) insisted on the critical dimension of the curriculum, which should help students to develop skills needed to examine critically the current political and economic structure.

Since in the year 2000 Castilla La Mancha took over the competences related to education, many changes regarding multiculturalism have been introduced in this region. A wide network of support has been created, intending that teachers work together, promoting professional cooperation, and that students provide help to other classmates.

Some of the first steps included the creation of the Language Support Teams for Immigrant or Refugee Students in 2002. The School Board of Castilla La Mancha approved them, initially as experimental teams.

\section{Theoretical background}

Firstly, it is important to clarify the terminology, as we can find the same meaning expressed with different words. The terms of multicultural and intercultural education have been discussed for some time. Multicultural education and intercultural education are often used as synonyms (Nieto, 2006; Hill, 2007). In the multicultural and intercultural literature it is often unclear what the concepts mean and whether they are referring to the same or different things.

If we revise the UNESCO guidelines on intercultural education (2005: 17), 'multicultural' would describe the culturally diverse nature of human society, and refers to ethnic or national culture, including linguistic, religious and socio-economic diversity, without including aspects such as gender or race; whereas intercultural "presupposes multiculturalism and results from intercultural exchange and dialogue on the local, regional, national or international level". This perception can also be found in the Council of Europe and the European Union Commission, which are including in their policies the term intercultural education.

This theoretical distinction between multiculturalism and interculturalism can show the term 'multicultural' as more static, describing just a situation with a diversity of cultures, while 'intercultural' is used to indicate the interaction and relationship between different cultural groups in a culturally diverse setting (Hill 2007: 250). The fact is that, in practice, both terms can be considered as synonyms. Therefore, in this paper we will focus on the term multiculturalism.

The concept of multicultural education started to be used at the end of 1960s and the beginning of 1970s. It started as a new insight towards education and related to the concepts of school normalization and integration. Its main proposal is that all the students must have the same opportunities in education, independently from their racial, ethnic, social class, or gender background (Banks 2001a, 2001b, Mwonga 2005 in Yilmaz 2016). This innovative perspective aims to achieve a wider change in schools, fostering equal opportunities. Reaching equal educational opportunities for all the students will result in 
the improvement and sustainability of democracy, and therefore improve the existing social structure (Gorski 2009, Kim 2011).

As Day (2000) indicates, Canada was the first country in the world to adopt multiculturalism as an official policy in 1971 to achieve unit through diversity. This country was a pioneer, establishing, in 2002, the $27^{\text {th }}$ of June as the Canadian Multiculturalism Day. This day celebrates the diversity of Canada highlighting values like democracy, equality and mutual respect. Multiculturalism recognizes Canada's diverse races, religions, languages and traditions enrich this shared national identity.

Also, in other countries the path of multiculturalism has been followed during the last third of the twentieth century and the first decades of this one. In Europe, different actions taken by the European Union had an effect in legislations of its countries. According to the definition given in the European Commission webpage, multiculturalism is:

A policy that endorses the principle of cultural diversity and supports the right of different cultural and ethnic groups to retain distinctive cultural identities ensuring their equitable access to society, encompassing constitutional principles and commonly shared values prevailing in the society. (European commission 2019)

We can find different actions at a European, national and regional level, concerning multilingual education. At a State level, it is important to mention the Spanish Education Act of 2006 (LOE), modified by the Spanish Quality of Education Act in 2013 (LOMCE). In both laws, several measures are included towards a multicultural view of teaching. Among the key competences established, the social and civic competence is a valuable tool to educate pupils in the awareness of social and multicultural values. Also, the stage objectives established for primary and secondary education focus on different aspects related to multicultural issues, such as knowing, understanding and respecting different cultures and the differences among people, equal rights and opportunities for men and women and non-discrimination of people with disabilities (Stage Objectives of the Curriculum Decree 126/2014, Article 7).

According to Rodríguez Navarro et al. (2010) there have been many initiatives about intercultural education in Spain and intercultural teaching practices have become a reality throughout the country in the last decades.

Attention to linguistic and cultural diversity is a key aspect for the integration of students from other countries, especially as a vehicle to access the curriculum. Schools usually have the linguistic measures included in their welcome plans. These actions are carried out not only as a learning of the new language but also as a transitory process of adaptation to the new environment and of knowledge to the cultural codes of the school (Rodríguez Navarro \& García Monge 2006, 2009).

This is included in welcome plans to host the new students, as recommended by the current legislation (Spanish Education laws LOE 2006 and LOMCE 2013). They are elaborated considering the entire new population as well as immigrant groups. That is, the difference between generalized measures or specialized ones related to immigrants. Some regions have their own plans at a regional level to carry out this reception of new students. In the case of Castilla La Mancha, the reception is developed within the plans of attention to diversity. There are also specific socio-linguistic and personal reception classrooms to support this aspect, such as the teachers of the linguistic teams.

There is not a specific legal corpus regarding multicultural education in Castilla La Mancha, unlike other regions, as the Andalusia Law 9/1999, on Solidarity in Education, which reflects the coexistence with the gypsy community and points out the increase of students belonging to other cultures. This law aims to attend this source of diversity and cultural plurality by promoting specific mechanisms and strategies that enhance in the schools the value of interculturality and to develop in the community educational attitudes of respect and communication among cultures.

Another relevant issue is teacher training, as it is directly linked to the success of educational actions regarding multiculturalism. The regional educational administrations have adopted some measures 
preparing teachers for newcomer students with different backgrounds to their schools. Although it is not a priority in university teacher training, different formats have been provided to ensure that this training is available for career teachers and specifically on issues related to interculturality. There is a training offer for teachers, advisors and education authorities, even with immigrant associations that carry out different workshops, seminars, postgraduate courses, and training in schools. There are also courses on this subject, specifically intended for management teams, to work on the different forms of organization of the centers and actions that their governing body can carry out. It is important to generate networks and find common spaces to collaborate with the Universities, more specifically, the faculties of education.

\section{Methodology}

In order to analyze the evolution of the multicultural policies related to education in CLM, a bibliographic research has been conducted, focusing on more general aspects related to multiculturalism and on more specific issues related to the region. The outcome was that there has been no previous study investigating the multicultural education at the regional level.

In different search engines, we intended to find relevant laws, documents, reports, articles or any other kind of material which could be helpful in order to contextualize multiculturalism in the reality and recent history of Castilla La Mancha.

Searching the concept multiculturalism in the bibliographic platform Dialnet (28 ${ }^{\text {th }}$ November 2019) we find 1446 documents according with this topic. In the same way, when we use the same term in Spanish, "multicultiralismo", the results that we get are 8054. Continuing with this research, in the webpage of the Spanish Government based in $\mathrm{PhD}$, there are 19 doctoral theses about multiculturalism. The last "scanner" of the term made in Google Scholar, we find 595 articles in English and 48300 in Spanish. So, we can assert that the topic interests a lot of people, considering the raw data.

A selection was done on the basis of their relevance, focusing on the topic of multicultural education in Castilla La Mancha. Surprisingly, no articles analyzing the evolution of these policies in the region were found. In this way, this article offers the first brief compendium of the related legal framework and actions developed in the region regarding multiculturalism.

\section{Results and discussion}

In this section, the findings, in terms of sources obtained through desk-research methodology are going to be analyzed. The main legal framework at a Spanish and Regional level, including multicultural education regulations and the actions taken in Castilla La Mancha, will be presented.

Until the approval of the 1990 Spanish Education Law (LOGSE), there was no effective development of multicultural topics in the schools curricula. With the 1990 Law, the objectives and contents of the different areas in Primary and Secondary Education (Social and Natural Sciences, Spanish Language, or Foreign Languages) included various references to interculturality.

The LOE Law (2006) and the current Education Law LOMCE (2013), which modified the previous Law, present a differentiated spirit, regarding the multicultural character of schools and the society (Peñalva \& Sotés 2009). Multicultural Education is included since the 2006 Spanish Law of Education as a crosscurricular topic, in Primary and Secondary education. This legal framework at a national level is the basis to develop regional laws and instructions for each Autonomous community and school.

In Castilla La Mancha, the Order of July 8, 2002 regulated experimentally the structure, and intervention model of the Language Support Teams for immigrant or refugee students. The target group was the one of foreign pupils without knowledge of the Spanish language and newcomers in the schools of the region. Teachers from non-university levels supported by public funds would teach them. Since this law was approved, these teams are responsible for facilitating the development of basic linguistic and communicative skills to immigrant students, whose mother tongue is not Spanish, so that they can 
take part in the teaching process normally. These teams are made up of teachers whose teaching hours are adjusted to what is established for the rest of the teaching staff. Their timetable includes, the work with the students, as well as the coordination sessions with the management team, tutors, families and the educational counselling services. They also have to coordinate with the rest of teams participating in the program. The target ages of the linguistic support teachers, prioritizes the Primary Education and Mandatory Secondary Education stages (from six to sixteen years) and must conform to the following criteria:

- The period of attention to students consists of several sessions, some days a week. The rest of the school hours, students remain in their class;

- The intervention can be done both individually and in groups that may consist of students from different schools, taking into account certain criteria of homogenization, age and linguistic competence;

- The schedule for teachers among schools is done taking into account times and avoiding trips between educational centers in the same morning or afternoon. The headmasters of schools with immigrant students with no knowledge of Spanish must apply for the intervention of the linguistic support team. This can be done at any time during the course.

The basis for developing the multicultural education in Castilla La Mancha is the document proposed by the Department of Education of the region, approved in 2006, The Multicultural Education Document. The proposal highlights everyone's right to education in conditions of equality and assumes the commitment to compensate social differences and promote the practice of intercultural and democratic education.

The response to student diversity is ruled, in the region, by the principles of standardization, integration and educational inclusion, compensation of inequalities, empowerment and interculturality.

Thus, priority is given to normalization and general measures. This determines that the response must be organized in each school and must have as a reference the educational project of each school. The educational response to diversity must be part of the integrated responses addressed to all students. This can be possible in the framework of a school that provides also diverse, flexible and appropriate answers to achieve the maximum development of pupils.

Certain schools have a high number of students with specific educational needs, with greater problems of coexistence, absenteeism or with lower rates of school success. This means that some schools must develop their educational action in complex socio-economical environments, characterized by exclusion, inequality, social and school marginalization. These parameters constitute different starting conditions to respond to the needs of their students and of the educational community. This must be considered in terms of additional support by the educational authorities.

According to the Multicultural Education Document, the Castilla-La Mancha Education Department assumes the commitment to support, by providing human and budget resources and the necessary measures of academic organization and curricular changes in the schools. This especially in the ones that have greater starting difficulties and that are committed to actions that guarantee educational responses in conditions of equality and quality.

The Castilla-La Mancha proposal on multiculturalism aims to promote educational projects in the schools that can transform the reality by implementing inclusive educational practices with the collaboration of all agents and sectors of the educational communities.

The proposed document for intercultural education and social cohesion implies a model of commitment to inclusive schools, aiming to transform teaching practices and the organization of schools. A series of schools took part in the first phase of the application of the model.

Another relevant element is the Education Law of Castilla La Mancha (2010), which adapts the State Education Law LOE to the region. In the preamble, it mentions that it is necessary to develop educational models based on interculturality and educate in diversity with equity and social cohesion. The term is 
also mentioned among the guiding principles of the education system (Article 4), and among the objectives (Article 6), as well as in the response to diversity of students (Article 120). Especially relevant are the principles of equity of opportunities, universal access, standardization, school inclusion, social integration, flexibility and interculturality.

The 54/2014 Curriculum Decree in Castilla La Mancha mentioned multiculturalism in relation to social and civic values. It assumes some fundamentals: the teaching of emotional intelligence, the notions of good, freedom and responsibility, are formed in the first years of life. Therefore, if students develop social and civic skills, as well as interpersonal and intercultural ones, their learning will be filled with sense. Hence, it is very important to promote their development from childhood through the behavior stimulation and acceptance of the rules of coexistence that strengthen their identity in a plural society. Guiding students towards decision-making based on moral judgments, problem solving and collaborative conflicts will be a step forwards their multicultural competences.

Multiculturalism is also mentioned in the subject of Physical Education, within the frame of cooperative learning, linking the need to live and interact in society, allowing increased interaction between students, improving communication and the developing interdependence, interculturality, motivation and positive attitudes towards the teaching and learning process.

In February 2018, the Official Gazette of Castilla-La Mancha published a resolution that converted into law previous approaches and protocols used by school counselors to provide individualized and extraordinary measures for the educational inclusion of students in the regions' schools. These measures were included in the so-called school guides. After this change, since the 2020-2021 course the new regulation will be mandatory.

The adaptation of these school guides, giving them a legal format is done with the Decree 85/2018, which regulates the educational inclusion of students in Castilla-La Mancha and rules how schooling should take place. The resolution is a regulation that develops the decree of inclusion and makes clear the actions for students who need extraordinary measures.

The Reception guide for immigrants with intellectual disabilities in Castilla-La Mancha is another document offering attention to diversity in a multicultural dimension. It considers the needs of those students who have any kind of learning impairments, addressing additionally a new target group that had not been specified before, the one of immigrant children with special needs.

Another relevant initiative was the creation in 2014 of the Network of Multicultural Schools, an online platform to exchange experiences and support related to multicultural education among schools in the region. It was a result of the Sensitization Campaign Stop Racism: educate to find us, educate without exclusion. It aimed at teachers and students within the sensitization program for equal opportunities and intercultural living in education. It fostered education without exclusion, created by some trade unions with funding from the Department of Employment and Social Security of Castilla La Mancha. The initiative was co-financed by the European Asylum, Migration and Integration Fund.

The purpose of this campaign was to move towards an intercultural and inclusive school model, providing guidelines to prevent situations of racism, xenophobia and other practices of discrimination in the classroom. Several workshops were carried out, including the participation and expression of emotions and thoughts. Students were trained in attitudes and values of respect, equality, autonomy and mutual recognition. Regarding the collaborating schools, it intended to establish a means of communication of this classroom program with the schools, to be able to stimulate the exchange and participation of the schools. To this end, a blog was created, as an exchange and support platform among schools.

The Network of Multicultural Schools includes the following activities or contents:

- Information and access to materials, documentation, teaching tools, etc.;

- Dissemination of articles, positive experiences or good practices, reports, etc.;

- Dynamization and mediation between centers to share information; 
- Training information aimed at teachers. Online training;

- Participation in studies and research on interculturality and school.

In addition to this, during the last years, different support programs for intercultural education and social cohesion have been approved in Castilla La Mancha. These are the most relevant ones:

- Hispanic-Moroccan program of teaching Arabic language and Moroccan culture.

- Romanian Language, Culture and Civilization Program. This program is developed in accordance with Article 1 of the Agreement on Cultural and Educational Cooperation between Spain and Romania, signed in Bucharest on January 25, 1995 (BOE 03/15/1996). It is preferably aimed at Romanian students of Primary and Secondary Education, enrolled in schools maintained with public funds of Castilla-La Mancha, who wish to take the optional subject of Romanian Language, Culture and Civilization. It is open to the participation of students, families and Spanish teachers.

- Colour Tales (Cuentos de colores) consists of intercultural workshops and storytelling for the promotion of tolerance and coexistence between the different peoples that live in Castilla-La Mancha. It is developed, with the collaboration of the Department of Education by the "Llere" socio-educational association;

- The NGO SOLMAN (Solidarity in La Mancha) develops some artistic workshops to transmit general knowledge about the African continent, approach its culture through music and dance and reflect on interculturality and cooperation;

- The NGO SOS Children's Villages (Aldeas Infantiles-SOS) is a private international organization to aid children, non-profit and independent of any political orientation, organizes the contest "Values from SOS Children's Villages";

- The NGO ACCEM Collaborates with schools, mainly in the province of Guadalajara, in mediation and intercultural activities;

- The foundation IPADE develops actions, like the sensitization of children towards the United Nations millennium goals. It conducts workshops on the Millennium Development Goals;

- The association Cooperation Assembly for Peace develops a program of activities called "School without Racism", mainly in the province of Albacete;

- The association Maná-Ayuda al Desarrollo is an NGO that finances and supports cooperation projects in developing countries. In addition, it also has the fundamental objective of raising awareness of the problems suffered by Third World countries.

As we have seen, there are several actions and regulations that are being developed in Castilla La Mancha, promoting multiculturalism in schools and in different fields of society.

The Order of July 8, 2002 implied a very important first step towards multiculturality, though specifically applied to the linguistic integration of immigrant children in the regional education system.

The 2006 Multicultural Education Document set the basis, as we have seen, for the development of multicultural strategies and organization, in the case of schools.

The 2010 Education Law of Castilla La Mancha included references to intercultural (but with the meaning of multicultural) values to be implemented in the school system of the region.

On its side, the 2014 Curriculum Decree for Castilla La Mancha included some references to multicultural education but without developing them more in depth.

Finally, the 2018 Inclusive Education Decree includes multiculturalism within the regulations though not properly linked to the Curriculum Decree of Castilla La Mancha that was itself not enough developed in terms of including methodological strategies to foster multicultural education.

As it has been reflected in this paper, we can see an evolution of the multiculturalism policies in the Castilla La Mancha region. We must highlight that there are no specific laws regulating multicultural education, although we can find it as part of educational acts in the region and other legal regulations in other departments. As a result, many different actions have been developed in the last decades but not under the same legal regulations. 
Considering that the actions affect different Departments in the region (Education, Social Affairs, Health Department), the regulation of those actions in one unified act would help to enhance the coordination, implementation and funding. In other regions, specific acts regarding multiculturalism have been passed, like the 1999 Andalusian law. Therefore, a regional law regulating multicultural education in different fields, could be useful in this sense.

\section{Conclusion}

The attention to diversity was a fundamental principle of the educational model proposed by the Spanish State Law LOGSE in 1990. This legal evolution is the result of some essential principles, considering the different learning needs from a functional model, based on an interactive conception of development. In this sense, the capacities of the students are developed according the educational intervention, valuing the difference as a resource to improve education. Hence, having immigrants of foreign origin in the society and in schools will increase our ethnic and cultural plurality. These differences provided by immigrants must be addressed and seized in the schools.

In spite of the fact that the legal development has not encompassed the reality of social and school changes, notably teachers of the school system in the region have done an important effort to adapt their teachings to the new and changing social reality.

Together with the actions developed in the schools, we can affirm that all these actions conducted by different departments, associations, NGO's and other institutions have constructed a policy stepping towards multicultural education.

According to Martínez Lozano (2015), the inclusion of interculturality in school counselling programs should not be considered as a mere intervention with immigrants. As society is progressively multicultural, we are facing a reality in which coexistence and work with people of different cultures becomes increasingly common. This implies that all citizens need such intercultural skills. Real inclusion will only be achieved if people have such competencies, so that they can preserve their own cultural identity but have, themselves, the capacity to act properly in another culture and learn to coexist with other cultures.

When reflecting on multicultural education, teachers should assume a clear position, in order to be able to organize and guide the pedagogical actions aimed at dealing in an integrative way with the contents belonging to different cultures. Though it is a challenge to reduce the difficulties that may arise, the knowledge that teachers can acquire may be determining to overcome them. This can be helpful to begin a new educational insight regarding diversity.

\section{References}

Ainley, J. \& R. Carstens (2018). Teaching and Learning International Survey (TALIS) 2018 Conceptual Framework. OECD Education Working Papers, 187, OECD Publishing, Paris. http://dx.doi.org/10.1787/799337c2-en

Aguado Odina, M. T. (2000). Prólogo, in: M. Bartolomé Pina (Ed.), La construcción de la Identidad en contextos multiculturales, Madrid, CIDE, Ministerio de Educación, Cultura y Deporte, Secretaría General de Educación y Formación Profesional, 346.

Convenio de Cooperación Cultural y Educativa entre España y Rumania, firmado en Bucarest el 25 de enero de 1995. Publicado en: BOE 65 (15), 10270-10271.

Banks, J. A. (1986). Multicultural Education: Development, Paradigms and Goals, in: J. A. Banks \& J. Lynch (Eds.), Multicultural Education in Western Societies. London: Holt, Rinehart and Winston, 2-28.

Banks, J. A. (1989). Multicultural Education: Traits and Goals, in: J. A. Banks \& C. A. Banks, Multicultural Education. Issues and Perspectives, London: Allyn and Bacon, 2-26.

Banks, J. A. (2001a). Multicultural education: Goals, possibilities and challenges, in: C. F. Diaz (Ed.), Multicultural education in the $21^{\text {st }}$ century, New York, NY: Addison-Wesley, 11-22.

Banks, J. A. (2001b). History, characteristics and goals, in: J. A. Banks \& C. A. M. Banks (Eds.), Handbook of research on multicultural education, New York, NY: Wiley, 3-29. 
Day, R. J. F. (2000). Multiculturalism and the history of Canadian diversity. Toronto: University of Toronto Press. Decreto 54/2014, de 10/07/2014, por el que se establece el currículo de la Educación Primaria en la Comunidad Autónoma de Castilla-La Mancha.

European Commission (2019). https://ec.europa.eu/home-affairs/what-wedo/networks/european_migration_network/glossary_search/multiculturalism_en

Gorski, P. C. (2009). What we're teaching teachers: An analysis of multicultural teacher education coursework syllabi. Teaching and Teacher Education, 25, 309-318. http://dx.doi.org/10.1016/j.tate.2008.07.008

Guía de acogida para personas inmigrantes con discapacidad intelectual en Castilla-La Mancha. Retrieved from: https://www.plenainclusion.org/informate/publicaciones/guia-de-acogida-para-personas-inmigrantes-condiscapacidad-intelectual-en

Hill, I. (2007). Multicultural and International Education: Never the Twain Shall Meet? International Review of Education, 53, 245-264.

Holm, G. \& Zilliacus, H. (2009). Multicultural education and intercultural education: is there a difference?, in: M-T. Talib, J. Loima, H. Paavola \& S. Patrikainen (Eds.), Dialogs on diversity and global education, Frankfurt am Main: Peter Lang, 11-28. Available from: https://www.researchgate.net/publication/281555019_Multicultural_education_and_intercultural_education_Is _there_a_difference

Kymlicka, W. (2016) Multicultural Citizenship: A Liberal Theory of Minority Rights. Canadian journal of law and society, 11 (2), 267-270. Doi: 10.1017/S0829320100004981

Kim, E. (2011). Conceptions, critiques and challenges in multicultural education reform the U.S. KEDI Journal of Educational Policy, 8, 201-218.

Ley 9/1999, de 18 de noviembre, de Solidaridad en la Educación. Comunidad Autónoma de Andalucía «BOJA» núm. 140, de 2 de diciembre de 1999 «BOE» núm. 304, de 21 de diciembre de 1999 Referencia: BOE-A-1999-24195

Ley Orgánica 8/2013, de 9 de diciembre, para la mejora de la calidad educativa. BOE núm. 295, de 10 de diciembre de 2013. Referencia: BOE-A-2013-12886

Ley 7/2010, de 20 de julio, de Educación de Castilla-La Mancha. Comunidad Autónoma de Castilla-La Mancha. DOCM núm. 144, de 28 de julio de 2010.

Ley Orgánica 1/1990, de 3 de octubre, de Ordenación General del Sistema Educativo. BOE núm. 238, de 4 de octubre de 1990, BOE-A-1990-24172. Permalink ELI: https://www.boe.es/eli/es/lo/1990/10/03/1

Martínez Lozano, J. (2015). Interculturalidad y orientación educativa. Ed Publicia. ISBN13 9783639645002

Muñoz Sedano, A. (1997): Educación intercultural: teoría y práctica, Madrid, Escuela Española.

Mwonga, C. (2005). Multicultural education: New path toward democracy. Education and Democracy.

Nieto, S. (2006). Solidarity, courage and heart: what teacher educators can learn from a new generation of teachers. Intercultural Education, 17, 457-473.

Peiró Grègory, S. \& Merma Molina, G. (2012). La Interculturalidad en la Educación. Situación y Fundamentos de la Educación Intercultural Basada en Valores. Barataria. Revista Castellano-Manchega de Ciencias Sociales, (13), 127-139. https://www.redalyc.org/articulo.oa?id=3221/322127623008.

Peñalva Vélez, A. \& Sotés Elizalde, M. A. (2009). Evolución histórica del concepto de diversidad cultural en las leyes educativas españolas en comparación con la normativa europea sobre interculturalidad, in: R. Berruezo Albéniz \& S. Conejero López (Eds.) El largo camino hacia una educación inclusiva. La educación especial y social del siglo XIX a nuestros días, Pamplona, Universidad Pública de Navarra.

Real Decreto 126/2014, de 28 de febrero, por el que se establece el currículo básico de la Educación Primaria. Ministerio de Educación, Cultura y Deporte BOE 52 (1).

Rodríguez Navarro, H. \& García Monge, A. (2008). Proceso de integración de tres alumnos inmigrantes nuevos a través del análisis de las relaciones sociales establecidas por los iguales. Revista Pedagógica Tabanque, 21, 181191.

Rodríguez Navarro, H. \& García Monge, A. (2009). Asimilación de códigos de género en las actividades del recreo escolar. Revista Interuniversitaria de Formación del Profesorado, 64, 59-72.

Rodríguez Navarro, H., García Monge A. \& Retortillo Osuna, A. (2010). El prejuicio y la exclusión en los procesos de integración del alumnado en un centro escolar. Revista Migraciones, 27, 111-138.

UNESCO (2006). Unesco Guidelines for Intercultural Education. Paris: UNESCO.

Yılmaz, F. (2016). Multiculturalism and multicultural education: A case study of teacher candidates' perceptions. Cogent Education, 3 (1), 1-13. https://doi.org/10.1080/2331186X.2016.1172394 